\title{
LEGAL LINGUISTICS NO LONGER NEGLECTED: REVIEW OF LEGAL LINGUISTICS BY MARCUS GALDIA (REVIEWED BY ALEKSANDRA MATULEWSKA)
}

\author{
Aleksandra Matulewska \\ Adam Mickiewicz University in Poznań \\ Faculty of Modern Languages and Literature
}

\section{Legal Linguistics.}

Galdia, M., Frankfurt am Main: Peter Lang Publishing House, 2009, 434 pp., ISBN: 978-3-631-59463-6.

The need for research in the field of legal linguistics has been felt for a very long time. Bautro (1935:12) notices that

"The point, however, is that we need the description of the relationships between jurisprudence and linguistics as well as the idea of legal linguistics, and especially its main part, namely legal semantics. We accept not only a possibility, but also a necessity to form and conduct them. We think that in this way the research on law will be deepened, and the understanding and the formulation of its structure and functioning as well as its logics and action will be facilitated. What is more, we expect that then we will gain the proper foundation, examination and material for the legal theory and practice. Semantics (and linguistics in general) and logistics (that is logic) while interacting, will manage to elucidate all legal processes, all legal views, and in general logical structure of the world of human thoughts and acts in law".22

Despite those early voices of lawyers, who noticed the need to carry out research into the field, the first book on legal linguistics was published in 2006 (Legal Linguistics by Heikke Mattila). The second book on the topic has been written by Marcus Galdia and published in 2009. Those two authors are undoubtedly trailbrazers in that so-far neglected field.

22 'Nam jednakowoż chodzi o omówienie stosunków prawoznawstwa do językoznawstwa oraz o ideę lingwistyki prawniczej, a zwłaszcza o tejże główną część: semantykę prawnicza. Uznajemy bowiem możliwość, a nawet konieczność ich stworzenia i przeprowadzenia. Sądzimy, że w ten sposób pogłębi się dociekania nad prawem i ułatwi się zrozumienie i ujęcie jego struktury i funkcjonowania, jego logiki i mechanizmu. Mniemamy dalej, że tą drogą uzyska się należytą podstawę, sprawdzian i materiał dla teorii i praktyki prawniczej. Semantyka (i w ogóle lingwistyka) oraz logistyka współdziałając łącznie, zdołają dopiero wyświetlić wszelki proces prawny, wszelką myśl prawną, w ogóle logiczną budowę świata myśli i czynności prawnych.' 


\section{Comparative Legilinguistics 4/2010}

The book is composed of seven parts. The first part of the book, called Introduction, is in fact very long in comparison with the adopted standards. However, the reader instantly realizes that the complexity of the discussed issues justify such an elaborate introduction which constitutes foundations for discussing the issues in subsequent parts of the book.

In the first part of the book the author discusses the role of semantics and pragmatics in legal linguistics. Finally, he adopts the pragmatic perspective, which in his opinion is better as far as legal language (or language in law) description is concerned. The author also stresses the problem of the volatility of law, which as he puts it is "one of the most irritating aspects of law" and which affects legal construction.

Having presented in brief dyadic and triadic sign models' theories, the author vary accurately remarks that legal linguistics should be based on the interpretation on the basis of contextual assumptions and it does not suffice to base it solely on concepts and methods of traditional semantics that attempts to decode an alleged unequivocal meaning in legal texts.

The second part of the book is devoted to language and law. Firstly, the foundations of legal linguistics are discussed. The author presents in this respect a geographically-oriented brief description of the development of research into legal linguistics or law and language. The development of the reaserch into the language and law in the USA, France (also Canada), Russia, Poland, China and Scandinavia is presented. The deep analysis of publications on the subject matter, published nearly all around the world, astonish the reader. As far as Polish research is concerned, the author refers to articles by Brodziak and Petzel and publications of Kielar, Malinowski and a few other authors, and he fails to mention a few monographs devoted to that subject written by both lawyers and linguists such as: Kierzkowska (2002), Jopek-Bosiacka (2008), Matulewska (2007), Choduń (2007), Wronkowska and Zieliński (1993, 1997), Zieliński (1999), Lizisowa $(1983,1985)$, or the collective works of the Polish Legal Language Committee (Malinowska (ed) 2004), etc. As a Pole, investigating the field, however, I especially regret that the achievements of Zieliński (1999) (especially, the division of legal langauge introdued by him on the basis of the division of Wróblewski (1948)) have not been mentioned. As far as legal translation is concerned, one may not forget to mention here, that in 2008 a very interesting and long-awaited book by Jopek-Bosiacka (included by Galdia in the references) on legal translation and court interpreting was published in Poland, which in contrast to the publications of Kielar, mentioned by Galdia, for the first time are devoted not only to the problems connected with legal terminology translation but also text analysis for the purpose of translation and interpretetion (with the emphasis put on the interaction between civil law and common law language pairs). It is, however, understandable, that in the ubiquitous flood of publications on any topic, it is out of performance to read and mention all of them in any publication. I would like to stress again that the number of references, despite my subjective regret, is nonetheless impressive.

Galdia points attention to the fact that in the case of legal linguistics it is very difficult to provide the concept-oriented overview of pertinent reasearch due 
to a wide array of adopted approches and a multitude of perspectives. After the analysis of pertinent literature, he states that the majority of research has been carried out in the field of legal terminology.

Next, he refers to various approaches treating legal linguistics as a part of (i) semiotics of law, (ii) hermeneutics of law, (iii) introduction into law, (iv) comparative law, (v) forensic linguistics, (vi) interlingual comparison. Having later discussed why legal linguistics is not part of (i) philology, (ii) philosophy of law, (iii) sociology of law, (iv) law, (v) legal doctrine or (vi) logics for lawyers, he draws a conclusion that legal linguistics is a part of legal science rather than a part of linguistics despite the fact that it "deals with legally revelant aspects of language use".

Galdia, presents a fascinating and absorbing description of characteristic features of legal language or as he formulates it 'language used in law'. He focuses not only on terminology but also on other aspects of legal texts (for instance (i) phonology, (ii) morphology, (iii) syntax, (iv) semantics, as well as other textual aspects). He gives a wide range of examples, and I must honestly state, that the last time I have been comparably impressed, was when reading the well-known book by Mellinkoff (1963).

The third part of the book is devoted to the linguistic operations in law. The author elaborately discusses legal speech acts, legal discourse, different types of argumentation, legal interpretation, legal translation and other legal linguistic operations. Being a translator, I cannot fail to notice that Galdia (p. 229) very precisely points to the deficiencies of translation theories and approaches stating that 'Šarčević may be paradigmatic - concentrate rather on pragmatic aspects of legal texts and underscore the need for the development of general translation strategies'.

The forth part touches upon the impact of law on literature, or in other words the presence of law in literature.

The fifth part of the book, in turn, discusses the impact of globalisation on law and legislation (e.g. EU legislation), as well as the search for the original legal language and the attepts to revive Latin legal terminology deriving from Roman Law. materials.

Part six is composed of conclusions and part seven of notes and

To sum up, the book offers a wide ranging and elaborate survey of legal linguistics. The author brings up a wide array of issues. Although, some of them are discussed perfunctorily only (e.g. court interpreting - which is unavoidable to a certain extent), it cannot be denied that the book presents a survey of the pertinent issues on an unprecedented scale. As already emphasised, the book is definitely one of the two trailblazers in the field and gives the considerable insight into the field. The author has inspected legal linguistics in great detail and from many different perspectives. 


\section{Comparative Legilinguistics 4/2010 \\ Bibliography}

Alcaraz, E., Hughes, B. 2002. Legal Translation Explained. Manchester: St. Jerome.

Bautro, E. 1935. Idea lingwistyki i semantyki prawniczej. Lwów: Dom Książki Polskiej.

Cao, D. 2007. Translating Law. Clevedon: Multilingual Matters.

Choduń, Agnieszka, 2007. Słownictwo tekstów aktów prawnych w zasobie leksykalnym współczesnej polszczyzny. Warszawa: Wydawnictwo TRIO.

Jopek-Bosiacka A. 2008. Przekład prawny i sqdowy. Warszawa: PWN.

Kielar B. Z. 1996. Na manowcach thumaczenia tekstu prawnego: prawdopodobieństwo wywołania szoku kulturowego. F. Grucza, K. Chomicz-Jung (eds). Problemy komunikacji interkulturowej. Jedna Europa - wiele języków i wiele kultur. Warszawa: Wydawnictwo Uniwersytetu Warszawskiego, p. 135-141.

Kielar, B. Z. 1999. Translating Statutory Texts: in Search of Meaning and Relevance. Aspects of Legal Language and Legal Translation. J. Tomaszczyk (ed.). Łódź: Wydawnictwo Uniwersytetu Łódzkiego, p. 183-190.

Kielar, B. Z., 1973. Angielskie ekwiwalenty polskich terminów prawno-ustrojowych. Warszawa: Państwowe Wydawnictwo naukowe.

Kielar, B. Z., 1977. Language of the Law in the Aspect of Translation. Warszawa: Wydawnictwo Uniwersytetu Warszawskiego.

Kielar, B. Z., 2003. TS w układzie międzynarodowej komunikacji zawodowej. [W]: B. Z., Kielar, S. Grucza (red.). Języki specjalistyczne. Lingwistyczna identyfikacja tekstów specjalistycznych. Warszawa: Katedra Języków Specjalistycznych Uniwersytetu Warszawskiego. ss. 121 - 133.

Kielar, B. Z., Lewandowska, E. 1999. Towards Better Communication: Cultural and Terminological Aspects of Polish Translations of English Texts Relating to Copyright Law. Aspects of Legal Language and Legal Translation. J. Tomaszczyk (ed.). Łódź: Wydawnictwo Uniwersytetu Łódzkiego, p. 171-182.

Kielar, B. Z., Miler, J. 1993. Through the Looking Glass of Translation - the Verb Phrases of the Statutory Clauses in Kodeks Handlowy and Their English Renditions. International Forum of Legal Translation 1992. Proceedings. Warsaw: Polish Society of Economic, Legal, and Court Translators TEPIS, p. 41-53.

Kielar, B. Z.1979. Styl a język prawny. Państwo i Prawo, z. 3, p. 134-135.

Kierzkowska D. (ed.), 2005. Kodeks Ttumacza Przysięgłego z komentarzem. Warszawa: Wydawnictwo TEPIS Polskiego Towarzystwa Tłumaczy Ekonomicznych, Prawniczych i Sądowych.

Kierzkowska, D. (ed.). 1996. Polish Law Collection. Warsaw: Polish Society of Economic, Legal, and Court Translators TEPIS.

Kierzkowska, D. 1991. Kodeks thumacza sqdowego. Warsaw: Polish Society of Economic, Legal, and Court Translators TEPIS.

Kierzkowska, D. 1993. POLTERM Polish System of Unified Terminology. International Forum of Legal Translation 1992. Proceedings. Warsaw: Polish Society of Economic, Legal, and Court Translators TEPIS, p. 81-85.

Kierzkowska, D. 1997. On the Practice of Legal and Specialised Translation. On the Practice of Legal and Specialised Translation. Warsaw: Polish Society of Economic, Legal, and Court Translators TEPIS, p. 5-9.

Kierzkowska, D. 2002. Ttumaczenie prawnicze. Warszawa: Polskie Towarzystwo Tłumaczy Ekonomicznych, Prawniczych i Sądowych TEPIS.

Lizisowa, M. T. 1986. Z badań nad terminologią prawną. Rocznik Naukowo-Dydaktyczny WSP Kraków, Prace Językoznawcze, no. 5, p. 5-20. 
Lizisowa, M. T. 1995. Podstawowe terminy prawne $w$ statutach staropolskich na tle słowiańskim. Studium semantyczne. Kraków: Wydawnictwo Naukowe WSP.

Malinowska, Ewa (ed.). 2004. Język Prawo Społeczeństwo. Opole: Wydawnictwo Uniwersytetu Opolskiego.

Matulewska, A. 2007. Lingua Legis in Translation. Frankfurt am Main: Peter Lang Publishing House.

Mattila, H. 2006. Comparative Legal Linguistics. England: Ashgate.

Mellinkoff, D. 1963. The Language of the Law. Boston/Toronto: Little, Brown and Company.

Pieńkos, J. 1999. Podstawy juryslingwistyki. Język w prawie - prawo w języku. Warszawa: Oficyna Prawnicza Muza S.A.

Zieliński, Maciej. 1999. Języki prawne i prawnicze. Polszczyzna 2000. Orędzie o stanie języka na przełomie tysiącleci. Walery Pisarek (ed.). Kraków: Ośrodek Badań Prsoznawczych. Uniwersystet Jagielloński, str. 75-96.

Zieliński, Maciej. 2002. Wyktadnia prawa. Zasady. Reguly. Wskazówki. Warszawa: Wydawnictwo Prawnicze LexisNexis.

Šarčević, S. 1997. New Approach to Legal Translation. The Hague: Kluwer Law International.

Wronkowska, S., Zieliński, M. 1997. Zasady techniki prawodawczej. Warszawa: Wydawnictwo Sejmowe

Wronkowska, S., Zieliński M. 1993. Problemy i zasady redagowania tekstów prawnych. Warszawa: Urząd Rady Ministrów.

Wróblewski, Bronisław. 1948. Język prawny i prawniczy. Kraków: Polska Akademia Umiejętności. 